\title{
Research on Cultivation Mode of Digital Editing and Publishing Talents in Colleges under All Media Horizon
}

\author{
Jinmei Lv \\ Huanghe Science and Technology College \\ Zhengzhou, China 450063
}

\begin{abstract}
Publishing industry in China has entered into the digital era. The relationship between digital technology and publishing industry is increasingly close. New technology, new media development and information dissemination diversification tendency have raised new requirements for the employees engaged in publishing industry, and also provide new ideas for education and cultivation of digital publishing and editing talents in colleges. In the process of teaching reform, colleges shall innovate constantly, construct the diversified comprehensive system of digital publishing talents cultivation means, to promote comprehensive teaching reform in college education, and improve the overall college teaching quality, thus to construct practical teaching in colleges and the innovative talent training characteristics.
\end{abstract}

Keywords—all media; digital publishing; cultivation mode

\section{CURRENT Situation OF Digital MANAGEMENT TALENTS}

According to statistics, the current editing and publishing specialty in more than 200 colleges in China mainly takes digital publishing and editing direction as the major orientation of talent cultivation, providing more than 10000 graduates to the society each year. Currently, there is increasing demand for various digital publishing and editing talents nationwide, with conservative estimate as 6 million people. With great gap between talent cultivation and demand, human resources supply and demand is imbalance. Colleges should meet the needs of social development, make efforts to promote the reform of education and teaching management, increase the cultivation quantity and quality of digital publishing talents, and comprehensively improve the quality specification and standard of college talent cultivation, thus to excellent human resources for better development of all media.

\section{A. Dilemma Faced by Publishing Talent Cultivation in Colleges}

At present, the talents grasping digital publishing technology and digitized management are in great demand in China, and the talents with innovative thinking and innovative ability are particularly hot. The serious lack of talents has plagued digital process of our country.[1] With the rapid development of society, the traditional publishing industry and the new type of digital publishing enterprises, whether in paper or electronic media network, have an increasing need of large number of professional and technical talents. However, the knowledge structure of current personnel engaged in digital publishing has been difficult to meet the needs of rapid development of digital publishing industry. Especially after entering into the media merging age, the publishing specialty of higher education is urged to conduct teaching reform by the increasingly urgent situation. The employees engaged in publishing specialty also need to transform or enrich and expand their own strength in the trend of the times.

\section{B. Inconformity between the Cultivation of Editing and Publishing Professional Talents in Colleges and the Development of the Times}

Students graduated from colleges may only have learned the technical operation, mastered the basic theory of knowledge, lack of corresponding practical ability, or only grasp some theories in terms of communication and sociology, and few talents who can really combine theory application and practice operation. The college cultivation objective does not start from the perspective of publishing, but only limited to the cultivation of books editing talents. However, what the diversification of modern society needs are the all round editing and publishing talents of the media including books, newspapers, electronic audio and video and network. If such cultivation mode continues, publishing industry will recruit everywhere, while the graduates looking for a job around.

\section{Professional Setting of College Teaching}

Since entering into media merging age, the marketing methods of traditional editing and publishing activities are renewed, revealing the irrationality in course setting of editing and publishing specialty of higher education, showing the disadvantage of non-integration between education and practice, and lack of innovation in cultivation conception. The traditional teaching concept of emphasizing theory and neglecting practice has resulted in the contradiction between college graduates and employers. 


\section{CONSTRUCT THE CUltivation SYSTEM OF EDITING AND PUBLISHING SPECIALTY TALENTS WITH INDUSTRY DEMAND AS ORIENTATION}

Graduates will face employment difficulties when the cultivation cannot meet the demand. Now publishing industry is short of professional digital publishing talents, while the current editing and publishing graduates regret to be unable to give play to their talent. Colleges shall change the existing talent education and training mode, to form a new cultivation mechanism and employment strategy, to provide a number of innovative pioneer talents who can lead the publishing industry trend to the society. And this is the education and cultivation problem of colleges urgently to be solved.

\section{A. Survey and Analysis of Graduates Specialized in Editing and Publishing}

According to statistics, only $51.9 \%$ of the graduates specialized in editing and publishing are employed within editing and publishing industry. However, from the employment standard of foreign publishing enterprises, the talents with strong application ability are increasingly favored by employers. Most of Chinese publishing companies need more professional and skilled talents, and the employment positions need profound knowledge involving education, economy, law, medicine and other disciplines. People with single knowledge structure is no longer suitable for the requirements of modern publishing work, especially the technical personnel management, sales etc. in the digital age, the employees' computer application ability shall be specially emphasized.[3]

\section{B. Education and Cultivation Concept Transformation of Colleges Urged by the Industry}

In comparison with the traditional cultivation mode, the industry-oriented talent cultivation mode not only attaches importance to the learning of basic theory, but also pays attention to the cultivation of practical ability and operation ability; not only requires graduates to have publishing industry background, but also requires graduates to be familiar with the professional background of multiple fields. Colleges need to change and innovate from the cultivation mode with the cultivation of applied and compound digital publishing talents as the main target, cultivate students' planning and creation, analysis and processing ability in publishing abilities with emphasis, and focus on cultivating the applied and compound talents who are good at planning, designing and editing as well as other new media industrial technology and management position in digital publishing industry [4].

\section{Requirements for Talent Cultivation Specification by Business Operation}

Now, the employment trend of Chinese publishing enterprise is transforming from editing and publishing specialty to non-editing and publishing specialty. In the recruitment of highly educated talents, publishing enterprises tend to select the talents with multidisciplinary and interdisciplinary background. Most of Chinese publishing enterprises need the applied talents, and they shall have the publishing commercial and literary planning ability, as well as excellent information processing ability. The brand construction and new products' innovation and service enhancement cannot be conducted without solid practical foundation and the comprehensive skills of publishing, and they are unable to be qualified for the job.

\section{ESTABLISH THE EDUCATION AND CULTIVATION Methods of College Digital Publishing TAlents}

College digital publishing specialty can cooperate with the applied specialties such information engineering and public management, of which the technology and strength can provide certain skills to digital publishing.

\section{A. Carry Out Top Design, Make Clear Cultivation Positioning}

1) Innovation and reform of teaching concept: In the cultivation process, colleges should change the cultivation type first of all, and integrate the professional quality and ability cultivation in the talent cultivation target, curriculum setting, education and teaching, teaching evaluation and so on, to build operational practice teaching mode and cultivate the applied and compound digital publishing talents; moreover, the school-running mode shall be reformed, strengthen vocational training, cultivate the technical and innovative talents, and establish the curriculum system combining academic education and vocational skills training, to realize the practical teaching system docking with the enterprise seamlessly; finally, pay attention to transform from focusing on theory teaching to double-driven teaching mode of theory teaching and practice teaching, build a variety of support platforms, such as subject construction and scientific research platform, university-enterprise cooperation platform, innovative entrepreneurial practice platform for collaborative innovation talent training.

2) Innovation and reform curriculum setting: Editing publishing specialty carries innovation and reform of education and teaching content, implements the talent cultivation mode of "industry-university-researchemployment", strengthens the cultivation of students' innovative consciousness and entrepreneurial ability, to establish the comprehensive three-dimensional long-acting teaching reform mechanism, and truly improve the cultivation quality of editing and publishing professional talents. Strengthen students' digital publishing subject selection and planning ability, application ability of modern publishing industry, digital editing and marketing ability. While paying attention to humanities and social sciences education, new media theory and other design of application courses shall be added, such as: network communication, information processing, digital multimedia production and other technologies, the industrial basic knowledge such management, relevant laws and regulations shall also be made available. The courses such as three dimensional animation creative technology, print media and electronic composition 
shall also be set for the students, enabling them to learn the integration and application skills of multidisciplinary course.

3) Innovation and reform of teaching staff: There is a saying goes that an accomplished disciple owes his accomplishment to his great teacher. In order to cultivate the applied talents with high-quality, a batch of guidance teachers with "better skills" shall be made available first of all. Currently, most of the domestic teachers of editing and publishing specialty haven't experienced practice and exercise, and they are not proficient enough in new knowledge and new technology. They have difficulty in teaching and reproducing the complex crossing and integration of multidisciplinary knowledge due to environment limit, being unable to provide students with practice and innovation space. Colleges shall provide professional teachers with the opportunities to observe and investigate in publishing organizations. At the same time, the experts in digital publishing industry can be invited to participate in curriculum design and specialty development, and the enterprise management experts, technicians, researchers in media industry can be invited to develop professional planning, curriculum setting and enterprise practice and other plans, to strengthen "seamless docking" between talent cultivation and society.

\section{B. Cultivation Methods of Practice Ability for Digital Publishing Talents}

Students' exploration ability of huge amount of information, planning ability and management ability shall be further cultivated for college digital publishing and editing talent cultivation, to constantly adapt to the urgent demand of digital era for the applied and compound publishing and editing talents with high quality and high level. Colleges should exert its resource advantage and try the cultivation methods of joint school-running, order-oriented cultivation and integration of industry-university-research, to realize diversified goal of talent cultivation, and continuously meet the needs for talents by industry subdivision.

1) Build a dual system of talent cultivation mode: College publishing houses shall make full use of the education resources of their own school, adopt the "dual" college cultivation mode, and strengthen the connection with relevant specialties such as computer, network technology, editing and publishing, and journalism. Conduct the in-depth practice and innovation in terms of teaching, regard university-enterprise cooperation as a choice for talent cultivation, and cultivate the specialized talents needed by publishing houses jointly with these specialties, such as digital publishing planning, digital content production, digital marketing and management talents, to make positioning of talent cultivation clearer, and talent cultivation and employment have more characteristics and advantages.

2) Adopt the mode of working-learning integration as well as industry-university-research integration: The government, school, industry and enterprises formulate the industryuniversity-research standard and regulation with joint efforts. The government should play a leading role, issue related policies, encourage and promote cooperation between enterprises and schools. Colleges shall be demand-oriented, explore and establish the talent cultivation mode to improve vocational ability, set up professional training and practice base, combine comprehensive quality education and ability training through orientation cultivation and training platform, enabling students to participate in the process of publishing project approval and operation, to find and cultivate talents in true and vivid project implementation process. Promote the talent cultivation mode reform of digital publishing specialty, and constantly highlight the characteristics of specialty construction, to truly improve talent cultivation quality.

3) Build industry dialogue, and establish communication platform for talent cultivation: First, college and publishing enterprise cooperate to teach, with market as the orientation, to output the cultivated talents directly. Second, strive to make publishing enterprises as the teaching practice base, to provide teachers and students with intuitive platform for learning about enterprise operation and industrial development. Third, adopt the methods of domestic and foreign cooperation teaching, to create a good education environment for cultivation of talents with international vision. Fourth, actively invite industrial experts and senior management personnel to provide guidance and exchanges. Take participate in practice and education cultivation visiting, to improve the comprehensive quality and practical ability.

4) Carry out the third-party teaching quality evaluation mechanism: Schools shall improve the standard of various links of education quality together with enterprises and the industry. And formulate the talent cultivation plan with the enterprises according to the standardization professional qualification examination organized by national industry, with the cultivation process to be managed jointly by school and enterprise. At the time of students' graduation and internship identification, invite the brother colleges, industrial organizations, enterprises and other third-party forces to participate in the teaching quality evaluation, to realize the diversification of evaluation subjects and evaluation methods, enabling the graduates' actual ability to be recognized by the professional industry.

\section{Cultivating Strategies for Application Practice Ability of Digital Publishing Talents}

1) Cultivate students' innovation consciousness: As the important cultivation objective, digital publishing talents' innovative practice ability cultivation shall have strong sense of the times and innovation consciousness. While performing education and cultivation, college shall involve the innovative thinking cultivation, ways and means, practice and exercises as well as ability evaluation into the whole process of talent education and cultivation. Editing and publishing personnel shall have relevant knowledge and ability of the disciplines such as economy, law, marketing and management, the ability of marketing research and analysis, the ability of planning and 
designing based on market demand, and shall be able to create publications with era characteristics.

2) Develop students' ability of professional technology: The most important aspect for digital publishing talents is the professional planning ability, including the essential professional ability, especially the core professional ability. Second, as for digital publishing professionals, they shall have information processing ability. In addition, digital publishing professionals must have good planning, coordination and management ability as well as the team spirit.

\section{CONCLUSION}

As an important part of cultural industry, publishing industry has been moving toward the direction of integrative development of traditional media and new media. The cultivation mode of publishing talents focusing on single specialty can no longer adapt to requirements of integration media development for compound and applied talents, and innovative media talent cultivation mode has become the general trend. As an important base for cultivation of editing and publishing professionals, colleges shall grasp the industrial development trend, thoroughly understand the dynamic and prospective development direction, adjust talent cultivation goal and direction, keep pace with the times, establish the talent cultivation system that meet industrial demand, assume the historical task of cultivating the media talents that meet media integration development, to cultivate a large number of compound and applied publishing professionals for industry development and transformation.

\section{REFERENCES}

[1] He Di. Discussion on Publishing Talents Professionalism and Cultivation Mechanism [J]. Modern Economic Information, 2014,(1).

[2] Li Yuan. Countermeasures for Higher Education Development of Editing and Publishing Specialty in Digital Times [J]. Young Journalist, 2014(3):91.

[3] Wu Peng, Cheng Fang. Research on Cultivation Strategy of College Publishing Talents in Digital Publishing Transformation Period [J]. Publishing Education, 2014,(2).

[4] Yu Yan. Exploration on College Innovative Talent Cultivation under Digital Publishing Concept [J]. Viewpoint, 2013,(12). 